\title{
Advanced Rhodococcus Biocatalysts for Environmental Biotechnologies
}

\author{
Anastasiia Krivoruchko *, Maria Kuyukina $『$ and Irena Ivshina \\ Institute of Ecology and Genetics of Microorganisms, Perm Federal Research Center, Perm State University, \\ Perm, 614000, Russia; kuyukina@iegm.ru (M.K.); ivshina@iegm.ru (I.I.) \\ * Correspondence: nast@iegm.ru; Tel.: +7-342-2808114
}

Received: 14 February 2019; Accepted: 27 February 2019; Published: 4 March 2019

check for updates

\begin{abstract}
The review is devoted to biocatalysts based on actinobacteria of the genus Rhodococcus, which are promising for environmental biotechnologies. In the review, biotechnological advantages of Rhodococcus bacteria are evaluated, approaches used to develop robust and efficient biocatalysts are discussed, and their relevant applications are given. We focus on Rhodococcus cell immobilization in detail (methods of immobilization, criteria for strains and carriers, and optimization of process parameters) as the most efficient approach for stabilizing biocatalysts. It is shown that advanced Rhodococcus biocatalysts with improved working characteristics, enhanced stress tolerance, high catalytic activities, human and environment friendly, and commercially viable are developed, which are suitable for wastewater treatment, bioremediation, and biofuel production.
\end{abstract}

Keywords: biocatalysis; environmental biotechnologies; actinobacteria; Rhodococcus; whole cell biocatalysts; cell immobilization

\section{Biotechnological Advantages of Actinobacteria of the Genus Rhodococcus and Approaches to Obtain Stable Biocatalysts}

Chemical contamination of the Earth is a global ecological problem. Billion tons of chemical wastes (petroleum hydrocarbons, heavy metals, synthetic polymers, plasticizers, pesticides, agricultural fertilizers, and dyes) enter the environment every year [1-8]. For instance, an estimated value of 250 million tons of plastics arrived in marine environments in 2015 alone [6]. The situation is complicated by novel groups of emerging persistent contaminants, such as microplastics (plastic fragments of sizes smaller than $5 \mathrm{~mm}$ ), endocrine disruptors (hormonal drugs, bisphenol A, surface active alkylphenols, flame retardants, and plasticizers, for example, dimethyl, dibutyl, and dioctyl phthalates), and pharma pollutants [4,6,9-12]. Although green chemistry, recycling technologies, and careful attitudes to goods and natural resources are factors reducing chemical pollution, this problem is still far from being solved. Biological removal of contaminants (bioremediation in or ex situ with stimulated or introduced degrading microorganisms, biocomposting, biofiltration, detoxification with enzyme preparations, anaerobic digestion, activated sludges, and other techniques) is considered to be the most effective and ecologically safe clean-up approach. Biological methods do not employ aggressive reagents and adverse conditions and often provide complete mineralization of pollutants $[1,9,11-15]$.

Actinobacteria of the genus Rhodococcus are well-known xenobiotic degraders [16-22]. These bacteria synthesize a wide range of disrupting enzymes, such as dehydrogenases, peroxidases, oxygenases, alkylsulphatases, nitrilhydratases, and phenolhydrolases. Oxygenases are most powerful of these enzymes because they are structurally and functionally diverse and have broad substrate specificities $[17,21,23-30]$. For example, 73 monooxygenases, 22 cytochrome P450 oxygenases, and 45 dioxygenases are encoded in the genome of the hydrocarbon-oxidizing Rhodococcus ruber strain IEGM 231, a microorganism able to utilize gaseous $\left(\mathrm{C}_{2}-\mathrm{C}_{4}\right)$ alkanes. Moreover, diverse genes coding for monooxygenases ( $m m o A B C / p r m A$, 
alkB, flavin monooxygenase, and cyclohexanone 1,2-monooxygenase) were recovered in this strain [31]. In the genome of the polychlorinated biphenyl-degrading Rhodococcus jostii strain RHA1, 203 oxygenase genes with particular overrepresentation (19) of cyclohexanone monooxygenase genes were found [32,33]. This makes Rhodococcus able to assimilate a wide range of organic compounds: linear and branched alkanes $\mathrm{C}_{2}-\mathrm{C}_{30}$, cycloalkanes, benzene and its homologs, polycyclic aromatic hydrocarbons (PAHs), phenols, aromatic acids and their derivatives, halogenated hydrocarbons, including polychlorinated biphenyls (PCBs), nitriles, esters, isoprenoids, organic sulfides, nitrosubstituted organic compounds, $\mathrm{N}$ - and S-heterocyclic compounds, and synthetic polymers [16,18,21,24,34-38]. Rhodococcus strains are used for detoxification of dangerous chemicals, for example PAHs, PCBs, explosives, pharmaceuticals, endocrine disruptors, and pulp and paper wastes [18,20,21,34,38-40], in bioremediation [19,41] and plastic biodegradation $[36,42,43]$. Remarkably, rhodococci can attack polyethylene, one of the most abundantly produced and recalcitrant synthetic polymers [44].

Concerning biosynthetic capabilities of Rhodococcus, they are able to produce glycolipid biosurfactants [17,45,46], triacylglycerols [47], and polyhydroxyalkanoates (PHAs) [48,49]. Rhodococcus biosurfactants can be used as surface-active agents for the removal of hydrophobic pollutants from soil and water. They are nontoxic, even in comparison with other microbial surfactants, and show high desorbing, emulsifying, and washing activities towards hydrocarbons and their derivates $[45,46,50]$. Rhodococcal triacylglycerols are appropriate lipids for production of biodiesel, a renewable energy source intended to replace petroleum-based fuels [47], and PHAs are the basic compounds for production of bioplastics [51].

There are several biological features of rhodococci that make them attractive for environmental applications. Among 67 Rhodococcus species (List of prokaryotic names with standing in nomenclature, http:/ / www.bacterio.net/rhodococcus.html), only one species, Rhodococcus hoagii comb. nov. (formerly Rhodococcus equi), belongs to opportunistic human pathogens (risk group 2), and Rhodococcus fascians is phytopathogenic $[22,52,53]$. It therefore requires no special occupational health precautions during application processes. Rhodococci are ubiquitous, they inhabit soils, surface and subsurface water bodies (rivers, springs, ponds, stratal waters, and marine environments), bottom sediments, and plant surfaces around the world [22,54-56]. As autochthonous microorganisms, they are ideally adapted to local environmental conditions including temperature, moisture, aeration level, ionic composition, presence of specific chemicals, and type of soil [54,56-58]. In some regions, the introduction of allochthonous microorganisms is restricted [59], which should be considered during in situ bioremediation. Rhodococci are frequently isolated from hydrocarbon-contaminated ecosystems where they often dominate. These bacteria have comparative advantages over other hydrocarbon-oxidizing microorganisms, such as intracellular pool of hydrocarbons and storage lipids, low levels of endogenous respiration, oligotrophy, direct passive transport of hydrocarbons into cells, lack of catabolic repression, and extremotolerance $[54,56]$. As a result, Rhodococcus strains are able to maintain their metabolic activities in a wide range of temperatures $\left(-2-+40^{\circ} \mathrm{C}\right), \mathrm{pH}(3-11)$, and $\mathrm{NaCl}$ concentrations (0.5-7.0\%). Rhodococcal hydrocarbon-oxidizing activities are detected in many regions with cold and temperate climate, particularly in the Urals and Siberian parts of Russia, north Canada, the Arctic, Antarctica, and high mountains [19,56,59-62]. Moreover, rhodococci are resistant to toxicants like organic solvents and heavy metals. The organic solvent-tolerant Rhodococcus opacus strain B-4 survived for at least 5 days in $n$-tetradecane, oleyl alcohol, and bis(2-ethylhexyl)phthalate, which contained water less than $1 \%(\mathrm{w} / \mathrm{v})$ [63]. Minimal inhibitory concentrations of heavy metals $(\mathrm{Cd}, \mathrm{Cs}, \mathrm{Cr}, \mathrm{Cu}, \mathrm{Mo}, \mathrm{Ni}, \mathrm{Pb}, \mathrm{Zn}$, and $\mathrm{V})$ for Rhodococcus reached up to $250 \mathrm{mM}$; moreover, rhodococci were able to detoxify heavy metals and metalloids (As), changing their oxidation level $[64,65]$.

Both Rhodococcus whole cells and purified enzymes are currently used as biocatalysts. Enzymatic catalysts guarantee high reaction selectivity and the absence of side reactions, while whole cells perform multi-step bioconversions and allow easy cofactor regeneration [66]. In any case, the most important parameter is the economic viability of a biocatalytic system, which depends greatly on the system's stability. Here, the term "stability" includes a constant rate of the biochemical process(es) catalyzed, 
biocatalyst resistance to adverse conditions (toxic compounds, non-optimal temperature, salinity, or $\mathrm{pH}$, starvation, and etc.), long-term storage without catalytic activity losses, and re-usability. The following approaches could be used to obtain stable Rhodococcus biocatalysts: (1) immobilization, (2) genetic modification, (3) cell acclimation, and (4) construction of multi-species consortia/associations. Immobilization of rhodococcal cells on or into the carrier is the most common approach since it is feasible and provides solutions for a number of technical problems. Genetically engineered microorganisms are considered unwelcome by many government agencies; acclimation is time-consuming; and development of multi-component biocatalysts requires proper studies of all biological agents used [67]. In this review, we focus on immobilization of whole Rhodococcus cells and briefly describe other approaches.

\section{Guidelines for Immobilization of Rhodococcus on/into Carriers}

\subsection{Advantages of Immobilized Cells}

Immobilized cells (IC) represent a group of heterogeneous catalysts and have the following advantages: a strongly concentrated biomass to provide effective concentration of catalytic units; the regulated contact area between "enzymatic factories" and a substrate; repeated usage; and facilitated separation of a biocatalyst. Immobilization minimizes cell losses and assures high cell loading without negative effects typical for the concentrated biomass, such as metabolic activity decrease and cell death. In comparison with suspended cells (SC), IC are protected from elimination by predatory protists, they are slow-growing and stress-resistant, have conventional storage and transportation form, high plasmid stability, and often increased catalytic activity [13,67-75]. Immobilization carriers can partly (ad)sorb the pollutant molecules, resulting in the decrease of their concentration and toxic impact. For example, the modified sawdust adsorbed up to $90 \%$ of heavy metal ions from contaminated water [76]. Furthermore, a diffusion distance between cells and a pollutant is shortened, and the (ad)sorbed pollutant molecules became readily biodegraded [77-79]. In contaminated soil, carriers act as bulking agents, facilitating aeration and moisture exchange, and therefore ensuring that microorganisms are sufficiently supplied with oxygen and water [78,80,81]. It is considered that, for heavy soils, addition of bulking agents is more important than choice of a bioremediation method (biostimulation or bioaugmentation); and examples are known of heavy soils that when supplemented with a bulking agent alone resulted in a significant increase of biodegradation rates [80-82].

However, regarding the aforementioned advantages, a suitability of whole cell immobilization for biocatalysts is still discussed. No differences between IC and SC and even partial losses of catalytic activities or stress resistance of bacterial cells after immobilization were revealed [69,83-86]. Each biocatalytic system is unique and its efficacy depends on many factors, such as biological properties of microorganisms and their response to a certain immobilization procedure, specificity of enzyme regulation in the cell, carrier features, and possible diffusion problems. It is generally accepted that immobilization favors the tolerance phenotype in bacteria, namely a high level of shock (heat, cold and osmotic) protein expression, a cytoplasmic membrane enriched with saturated fatty acids, and a specific cell wall glycoprotein profile associated with decreased cell envelope permeability. As shown by many authors, increased catalytic activities of IC could be a result of their enhanced tolerance to toxic substrates or extended cell loads achieved by immobilization [84,87]. For immobilized rhodococci, enhanced catalytic activities and increased tolerance were reported [13,40,68,88-91], as well as the lack of significant differences with SC [70,83,85,92-96]. In reference [70], the authors clearly demonstrated that, although immobilized Rhodococcus cells were similar to suspended ones and even underperformed them in catalytic activities, immobilization allowed a convenient $\left(+4{ }^{\circ} \mathrm{C}\right.$, no humidity control) and long-term (12 months) storage of biocatalysts without losses in cell viability and functional activity.

In Figure 1, a general scheme for development of immobilized Rhodococcus biocatalysts is shown. It includes the following steps: (1) choice of the immobilization method; (2) selection of the most appropriate strain(s); (3) selection of a carrier and its improvement; (4) optimization of the immobilization process. 


\subsection{Choice of the Immobilization Method}

There are two common methods used for immobilization of rhodococcal cells: (i) adsorption [13,68,89,90,97-100] and (ii) gel entrapment (synonyms: involvement, embedment, and encapsulation) $[83,91,101]$. Adsorption is a technically simple procedure, which has the main disadvantage, namely partial desorption and elution of cells from a carrier. However for some carriers, cells could be washed out completely and the carriers could be regenerated and reused [13]. Moreover, adsorption is preferred in bioreactor applications since no separate immobilization step is required and the cells are adsorbed directly in the reactor [88]. A promising modification of the adsorption method is realized in membrane bioreactors. This type of bioreactor is equipped with a hollow-fiber ultra-filtration membrane cartridge on which the cells are adsorbed, directly forming a biofilm [102]. Immobilization of bacteria in gel carriers prevents cell losses, however, this procedure is more laborious and substrate diffusion problems may occur [72,78].

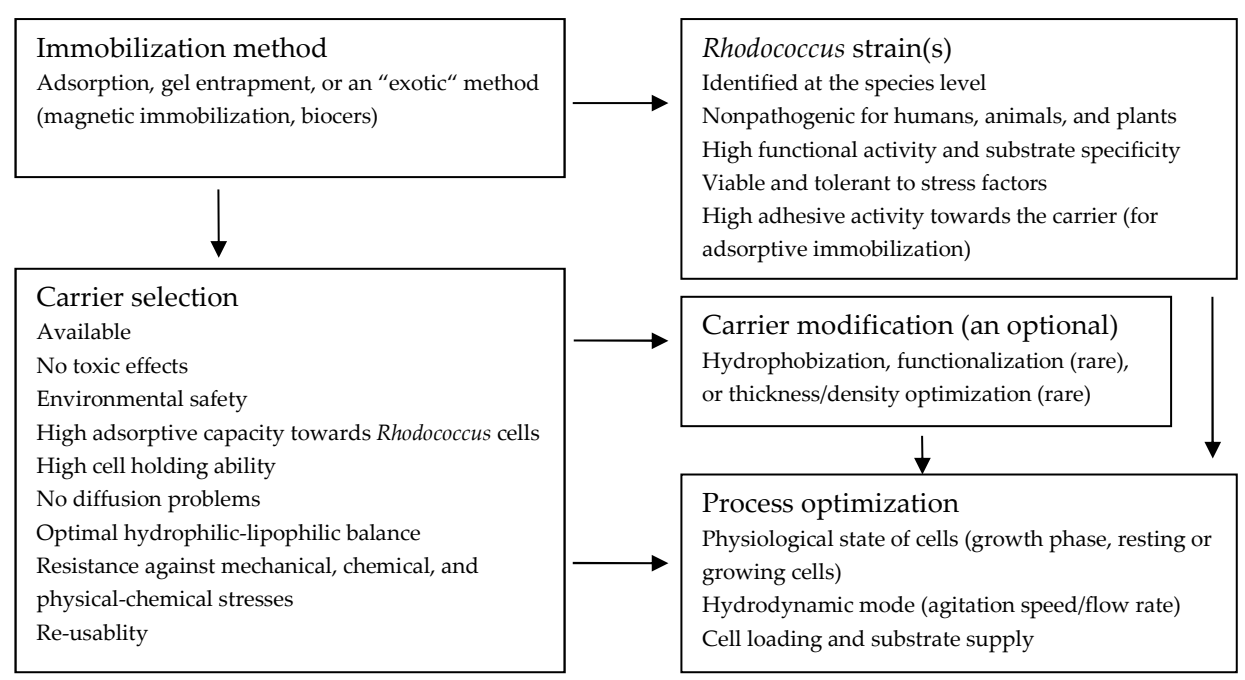

Figure 1. A general scheme to obtain stable biocatalysts based on immobilized Rhodococcus cells.

Recently, some advanced methods were proposed to immobilize Rhodococcus strains intended for environmental applications. In the work [96], Rhodococcus cells were magnetically held in the k-carrageenan gel. For this, freshly prepared soft k-carrageenan gel was mixed with Rhodococcus rhodochrous cells and $\mathrm{Fe}_{3} \mathrm{O}_{4}$ nanoparticles and then solidified. Magnetically immobilized rhodococci oxidized a target compound (2-chlorophenol) four times faster than SC or cells immobilized without magnetic nanoparticles. While particular mechanisms of these effects remain unclear, they are related perhaps to the increased contact area between cells and 2-chlorophenol, thus facilitating the substrate transfer into the cells [96]. In another work [70], rhodococcal cells were entrapped into porous ceramic-like materials. Cells were mixed with $\mathrm{SiO}_{2}$ nanosol and a filler (ceramic powder), then casted and frozen in the mold. The biocomposite (the biocer) obtained had the advantages of both adsorbed and gel-entrapped cells. It was chemically inert, easily stored (at $+4{ }^{\circ} \mathrm{C}$ in dry conditions for $6-12$ months), possessed a superior mechanical, chemical, and thermal stability, and had high open porosity.

With Rhodococcus enzymes, the same methods plus covalent binding and cross-linked aggregation are currently used for their immobilization. For example, the azoreductase AzoRo from Rhodococcus opacus strain 1CP was covalently immobilized onto the functionalized mesoporous silica, and this method was more successful than cross-linking [103].

\subsection{Selection of Bacterial Strains}

Basic requirements to biotechnological strains include high functional activity and substrate specificity, lack of pathogenicity, and simple (inexpensive nutrients, no special conditions) maintenance 
and cultivation. A wealth of relevant literature is associated with the proper description of these parameters. In this section, we focus on strain identification and adhesive properties of Rhodococcus strains used for immobilization.

In a number of works, Rhodococcus strains non-identified at the species level and indicated as Rhodococcus sp. are used $[12,68,92,104]$. As a result, possible pathogenic and phytopathogenic properties of these strains are unclear because they could belong to R. hoagii com.nov. (formerly R. equi), $R$. fascians, or be a representative of a new Rhodococcus species with unknown pathogenicity. Industrial application of such uncharacterized strains poses a serious risk for human health and the environment. Therefore, strict safety regulations are required to allow using only microbial agents with thorough defined biological features. For this reason, bacterial strains from well-known microbial collections (http://www.wfcc.info/ccinfo/) could be ordered, or genome sequence data should be obtained to properly identify the isolate(s).

High adhesive activities of bacterial strains and their ability to colonize surfaces are essential for adsorptive immobilization. Key biomolecules participating in Rhodococcus cell adhesion to solid carriers and mechanisms of their action are schematically shown in Figure 2. These are cell wall mycolic acids (specific long-chain $\alpha$-branched and $\beta$-hydroxy fatty acids) and extracellular polymeric substances (EPS), basically exopolysaccharides. Mycolic acids greatly impact cell-wall hydrophobicity, and EPS mostly affect zeta-potential of rhodococcal cells. Additionally, EPS content can vary significantly, resulting in cell hydrophobicity changes, namely in a ratio between lipophilic and hydrophilic areas on the cell surface $[92,105-110]$. As a rule, hydrophobic interactions dominate electrostatic ones in the bacterial adhesion process [106], although the number of adhered rhodococcal cells is not necessary in a linear dependence on hydrophobicity or zeta-potential values [111].
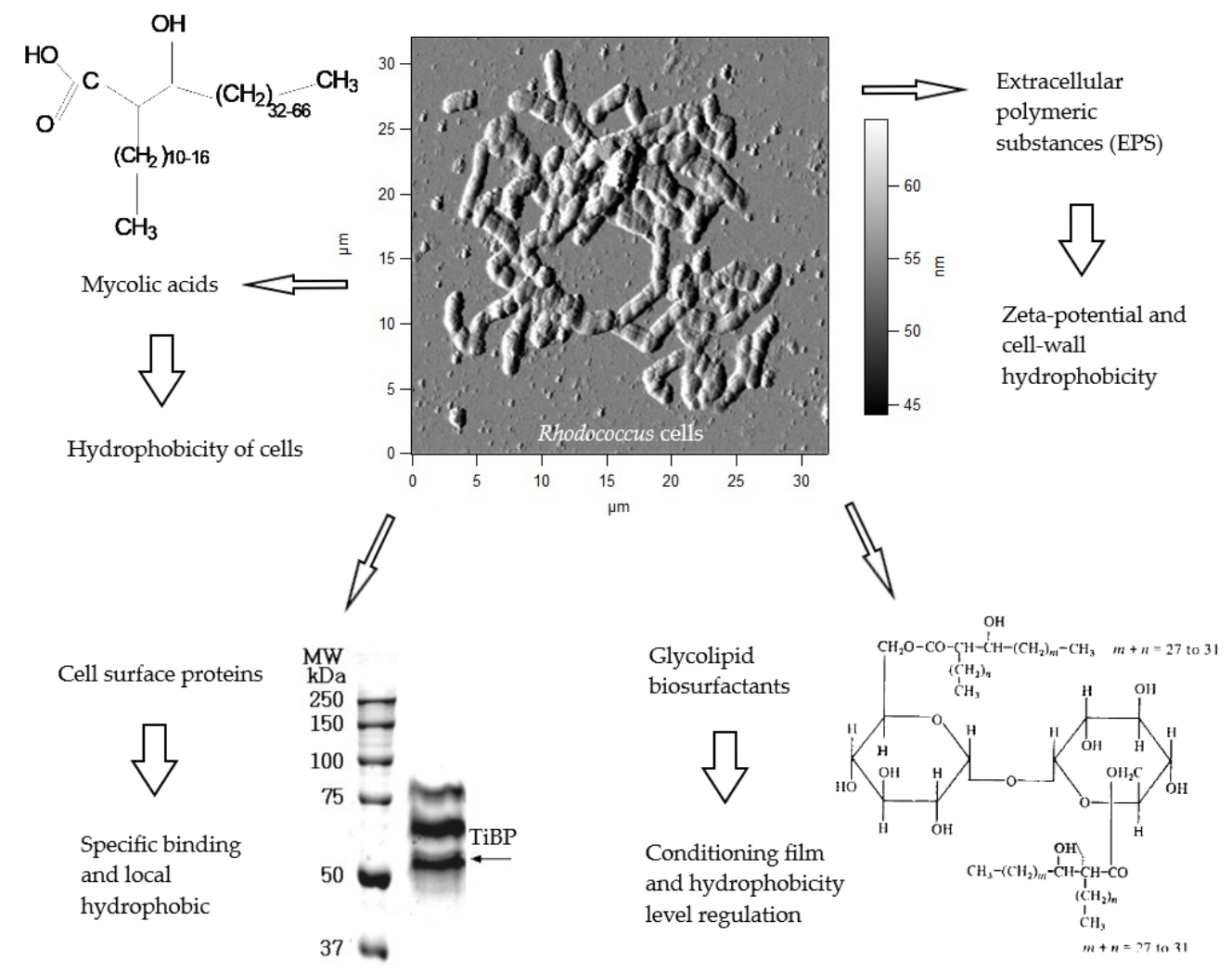

Figure 2. Key biomolecules participating in Rhodococcus cell adhesion to solid carriers and mechanisms of their action. An atomic force microscope image of Rhodococcus cells (the authors' original data, unpublished) is in the centre. A SDS-PAGE electrophoregram of a titanium-binding protein TiBP and a trehalose-dicorynomycolate structural formula are cited from reference [112] and reference [45], respectively. 
Glycolipid biosurfactants and cell surface proteins represent other Rhodococcus adhesion mechanisms, which are less studied in comparison to mycolic acids and EPS. In our studies, stimulating effects of glycolipid biosurfactants on rhodococcal cell adhesion to solid carriers were revealed. These compounds were shown to act as a conditioning film, which changes the hydrophobicity of the carrier surface [90]. Rhodococcus sp. strain GIN-1 had a titanium-binding protein TiBP that was responsible for selective adhesion to $\mathrm{TiO}_{2}$ and $\mathrm{ZnO}$. TiBP resembled a homodimeric dihydrolipoamide dehydrogenase, leading to bonds between rhodococcal cells and minerals via hydrophobic interactions [112-114]. In reference [115], treatment with proteinase $\mathrm{K}$ resulted in a reduced rhodococcal ability to co-aggregate with Acinetobacter calcoaceticus, although not all Rhodococcus strains tested were sensitive to this procedure. Apparently, protein adhesins of rhodococci are strain-specific and are involved in the adhesion to certain sites on biotic and abiotic surfaces.

\subsection{Selection of a Carrier for Cell Immobilization}

Basic requirements for the carrier materials include lack of toxicity, economical efficiency, availability, environmental safety, optimal lipophilic-hydrophilic balance, and high adsorptive capacity towards bacterial cells. For environmental applications, suitable natural organic materials for Rhodococcus cell adsorption include peat and plant residues, such as sawdust, lemongrass leaves, orange peels, sunflower husk, chopped straw, cumin seeds, corn cob grit, and walnut shells. These materials are light, volumetric, inexpensive, available, biodegradable, and have an extended surface area and high water-holding capacity. Additionally, plant residues can release essential oils and organic acids utilized by immobilized microorganisms as extra nutrients $[68,81,99,116]$. Animal-derived organic wastes, such as poultry feathers and leather scrap, are also reported as Rhodococcus cell carriers [117]. Among them, feathers have advanced flotation properties, and therefore, are suitable for surface water applications. Inorganic adsorbents include minerals (macrostructured foam ceramics, ceramic beads, corund, foamed vermiculite, diatomaceous earth, and coarse sand grains), as well as coconut shell-based granular activated carbon. There are also synthetic polymers (nonwoven fibers, polyurethane foam, and polycaproamide fiber), which are chemically inert and easily regenerated $[13,89,92,97,98,100,118]$. Selectivity of synthetic polymers towards hydrophobic compounds and rhodococcal cells could be improved using various modifications like saturation of surface with functional (alkyl, nitryl, and carbonyl) groups, thickness variations, and changes in the fiber packaging density [97].

Various gel-type polymers, both natural (agar, agarose, alginate, $\mathrm{k}$-carrageenan, and gellan gels) and synthetic (hydroxypropylcellulose, poly(N-isopropylacrylamide), poly(acrylamide), PAAG, and poly(vinylalcohol), PVA) are used for Rhodococcus cell entrapment $[83,85,91,96,101,119]$. Moreover, the advanced macroporous cryogels (hydroxypropylcellulose, poly(N-isopropylacrylamide), cryo-PAAG, and cryo-PVA) were developed, having a spongy-like structure of large pores (50-200 $\mu \mathrm{m})$ filled with water and surrounded by thin walls that favors diffusion of molecules and improves equilibrium sorption properties. Biological agents (cells or enzymes) are located inside the channels of such interconnected pores $[91,120]$. Cryo-PVA has additional advantages over other cryogels, namely high micro- and macroporosity, advanced water-holding capacity, perfect rheological properties, and relatively low biodegradability $[77,101]$. Among natural gels, $\mathrm{k}$-carrageenan has increased mechanical, chemical, thermal, and biological stability, and a loosened inner structure favoring substrate transport to bacterial cells [96].

Natural and biodegradable organic materials are preferable for in situ applications. They are environmentally compatible and can be left on site without the need to be removed and utilized. Inert inorganic carriers are perfect for contained systems, such as bioreactors and biofilters. These materials are easily regenerated and resistant to different stresses, for example a shear stress, overpressure, and mold damage [13].

Hydrophilic-lipophilic balance (HLB) is an important characteristic of Rhodococcus cell carriers since optimal thermodynamic conditions for biodegradation of hydrophobic organic pollutants 
occur at the border of polar (water) and nonpolar (hydrocarbon) phases. At the interface, hydrocarbon-oxidizing bacteria have an access to hydrophobic oxidized substrates, as well as mineral salts and essential micronutrients dissolved in water [90]. Normally, unmodified carriers (e.g., polymeric gels and raw plant residues) are hydrophilic and located in the water phase. To change their HLB values, Rhodococcus cell carriers should be hydrophobized. In the work [98], ceramic carriers were covered with a layer of graphitized or catalytic fiber carbon in order to increase the hydrophobicity. We tested drying oil, silicon emulsion, $n$-dodecane, $n$-hexadecane, mixture of paraffins, and Rhodococcus biosurfactants for the hydrophobization of sawdust, cryo-PVA, and cryo-PAAG $[88,90,116,119]$. Hydrophobization lead to the changed carrier location in a two-phase system (hydrophobized materials were located at the interface), 2-18-fold increases in the hydrocarbon sorption by carriers, and a 13\%-63\% increase in hydrocarbon-oxidizing activities of immobilized Rhodococcus cells. Moreover, the hydrophobization procedure protected sawdust from mold damage, while hydrophobized gels (in particular, $\mathrm{C}_{12}$-cryo-PAAG) retained more rhodococcal cells than intact gels. Interestingly, this procedure was ineffective towards the poultry feathers or leather scrap. Feathers were intrinsically hydrophobic and were located at the hydrocarbon-water interface, while leather scrap gravitated to the bottom, so hydrophobization did not improve its physical-chemical properties [121]. An optimal hydrophobizer concentration was found to be no more than $20 \%(\mathrm{w} / \mathrm{w})$, and the carrier over-hydrophobization (appeared as carrier localization in the nonpolar phase and the sorption of $\geq$ $60 \%$ hydrocarbons) resulted in significant reduction of immobilized cell numbers $[90,116]$.

Glycolipid biosurfactants produced by rhodococci seem to have optimal characteristics as carrier hydrophobizers because they are environmentally compatible, biodegradable, nontoxic, and hypoallergic, thus exceeding synthetic and many microbial surfactants in these parameters [50]. In our experiments, sawdust treated with Rhodococcus biosurfactants (5-10\%) had a high $\left(3.5 \times 10^{9}\right.$ cells $\left./ \mathrm{g}\right)$ adsorptive capacity towards bacterial cells, resulting in the $n$-hexadecane bio-oxidation rate of $35 \mathrm{mg} /(\mathrm{l} \cdot \mathrm{h})$ [90]. Biosurfactants covered the entire carrier surface, smoothing its fine irregularities, but saving general surface topography, which allowed a homogenous distribution of bacterial adhesion sites. Rhodococcal cells were adsorbed as a uniform monolayer biofilm and occupied all available sites on the carrier surface (about $50 \%$ of the total area) [122] that provided maximal cell loading and unlimited molecular diffusion. In comparison, hydrocarbons ( $n$-hexadecane, in particular) formed sporadic spots on the carrier surface, allowing rhodococcal adhesion on these spots in the form of dense cell clumps that resulted in a $20 \%$ decrease of their metabolic activities [90].

\subsection{Process Optimization Strategies}

One crucial parameter for Rhodococcus cell immobilization is a hydrodynamic mode. Rhodococci have morphological traits, significant for their immobilization, such as a complex morphogenetic cycle, cell polymorphism, and tendency to aggregate, especially in the presence of hydrophobic compounds. For example, at a low $(0.6 \mathrm{~mL} / \mathrm{min})$ flow rate in a fluidized-bed column bioreactor, rhodococcal cells were aggregated rather than adsorbed on the sawdust carrier [123]. These cell aggregates sedimented at the bioreactor bottom and prevented a normal bottom-up liquid flow. In the shaking flasks, the low (60 rpm) orbital mixing rate resulted in the irregular cell immobilization curve due to cell aggregations at different parts of a flask [124]. However, at very high flow $(2.8 \mathrm{ml} / \mathrm{min})$ or mixing $(210 \mathrm{rpm})$ rates, the sawdust carriers were destroyed, cell desorption was enforced, and cell (mycelium) fragmentation was initiated. Therefore, the optimal flow and agitation rates were found to be $1.2-2.0 \mathrm{~mL} / \mathrm{min}$ and 110-160 rpm, respectively, which did not impact cell morphology and immobilization efficacy, and provided cells with sufficient oxygen and substrate supply [123,124]. Additionally, in aerated bioreactors, the rate of aeration is important and should be set adequately since very intensive air bubbling results in strong cell desorption from the carrier [13,67].

Other parameters that are relevant for immobilization include cell growth phase and physiological state, as well as the cell concentration. For example, exponentially-growing Rhodococcus erythropolis cells were adsorbed faster on Biolite than their stationary-phase counterparts [13]. It should be noted 
that resting cells, i.e., washed from the growth medium and resuspended in the buffer, are more frequently used $[70,83,85,90,91,96,118]$ than growing cells $[13,67,93,102]$ due to easy control of their adhesion efficacy and catalytic activities. However, growing R. ruber cells were used, for example, in the propane-fed membrane bioreactor since its construction promoted the biofilm growth and a pollutant (N-nitrosodimethylamine) was degraded as a cometabolite [102]. Cell concentration effects were revealed in several publications [85,125], for example showing that a concentration of $10^{9} \mathrm{cells} / \mathrm{mL}$ was optimal for the adsorptive immobilization of $R$. ruber IEGM 231. At this concentration, the number of IC reached $2.5 \times 10^{7}$ cells $/ \mathrm{cm}^{2}$ or $30 \%$ of the initial number of the suspended cells. Although the number of attached cells was 3-5 times higher at concentration $10^{10}$ cells $/ \mathrm{mL}$, rhodococci were strongly aggregated, thus preventing efficient substrate biodegradation [125].

\section{Genetic Modifications of Rhodococcus}

Genetic and molecular biology tools are used for manipulations with Rhodococcus strains in three directions: (1) modifications of nucleotide sequences to improve industrially important characteristics, (2) heterologous expression of Rhodococcus proteins in suitable microbial hosts, and (3) application of Rhodococcus cells as expression systems to produce recombinant enzymes.

Modifications of nucleotide sequences in rhodococci were recently used to obtain overproducers of biofuel components, acylglycerols and fatty acids $[126,127]$. The ro00075 gene encoding phosphatidic acid phosphatase in $R$. jostii RHA1 was cloned in plasmid vectors containing strong promoters (either acetamidase promoter Pace or thiostrepton promoter $\mathrm{P}_{\text {tipA }}$ ). These vectors were transferred into $R$. jostii RHA1 and R. opacus PD630 cells. The ro00075 gene was overexpressed in transformants, providing enhanced dephosphorylation of phosphatidic acid to yield diacylglycerol, a key precursor for triacylglycerol biosynthesis. Transformation of the nonoleaginous $R$. fascians $\mathrm{F} 7$ with these vectors resulted in the $7 \%$ increase and with a vector containing ro00075 and atf2 (coded for wax ester/diacylglycerol acyltransferase) genes-the 4 -fold increase in the fatty acid content. Heterologous expression of the ro00075 gene in Escherichia coli resulted in the 4-fold and 2-fold increases in the phosphatase activity and the diacylglycerol content in the host cells, respectively [127]. In another work [126], the metabolic pathway of D-xylose utilization was introduced into the same Rhodococcus strains to force the production of triacylglycerols from a cheap substrate (xylose was one of major components of the lignocellulosic biomass). To achieve this, a vector, which harbored the $x y l A$ gene encoding xylose isomerase in Streptomyces lividans TK23, the $x y l B$ gene encoding xylulokinase in $S$. lividans TK23, and the tac promoter, was transferred into R. jostii RHA1 and R. opacus PD630 cells. The transformed cells were able to use xylose as the sole source of carbon and energy with high production of lipids. However, the main challenges for industrial applications of the overproducers obtained are the presence of marker genes coding antibiotic resistance in vectors, risk of vector elimination, and putative application of a phytopathogenic strain.

Rhodococcus sp. T104 strain was used as a cloning and expression system for $p h a Z_{\text {Sex }}$ gene encoding poly(3-hydroxybutyrate) depolymerase in Streptomyces exfoliates. A heterologous depolymerase was highly thermostable, keeping its functional activity at $40{ }^{\circ} \mathrm{C}$ and proposed for application in synthesis and degradation of bioplastics [128]. Three aromatic hydrocarbon dioxygenases, AhDOs, from Terrabacter sp. YK320, R. erythropolis TA42128, and R. rhodochrous K37 were expressed in host systems based on Rhodococcus sp. RD2 and R. erythropolis TA422, JCM 2892, and JCM 3201 under the control of the constitutive promoter $\mathrm{P}_{d f d B}$. These enzymes participated in oxidative degradation of dibenzofuran and chlorinated dioxins and were difficult to obtain in classical E. coli expression systems [129].

\section{Acclimation of Rhodococcus Cells to Toxic Substrates}

Cell acclimation to toxic substrates is a preliminary step in many biotechnological processes performed with whole bacterial cells. A disadvantage of this procedure is the long time required. For Rhodococcus, acclimation time varied between 2.5 and 13.0 days $[13,40,67,85,91,100,118,130]$. At the same time, acclimation guarantees higher initial rates of biodegradation with or without a shortened 
lag-phase. For example, consumption of 2,4-dinitrophenol by R. erythropolis HL 24-1 and HL 24-2 cells grown in the pollutant-free medium was preceded by a lag-period $(\geq 1 \mathrm{~h})$, which was eliminated when cells were preincubated with 2,4-dinitrophenol [85].

Two methods are currently used to obtain acclimated Rhodococcus cells: single batch cultivation in the presence of a pollutant, often at concentrations lower than working ones $[40,100,130]$, or sequenced cultivation with a gradual increase of the pollutant concentration $[13,67,91,118]$. For example, $R$. rhodochrous IEGM 608 cells were pre-grown in the presence of $0.0007 \%$ isoquinoline during 3 days prior to biodegradation of a pharma pollutant, drotaverine hydrochloride [40]. M.B. Prieto et al. [13,67] cultivated R. erythropolis UPV- 1 cells at increased phenol concentrations $(0.2$ and then $0.4 \mathrm{~g} / \mathrm{L})$ to obtain an acclimated culture. Rhodococcus bacteria used for detoxification of the NASA scrubber water rich in hydrazine, methylhydrazine (major constituents in a variety of rocket fuels and missile propellants), and citric acid, were serially conditioned with 5, 10 and $15 \%(\mathrm{v} / \mathrm{v})$ scrubber water before the commencement of experiments involving full strength wastewater [118]. In reference [91], ten cultivation passages were carried out with increasing concentrations of the xenobiotic (phenol) to obtain an adapted Rhodococcus wratislaviensis culture.

\section{Microbial Consortia/Associations Containing Rhodococcus}

Mixed microbial cultures are promising for biodegradation of multicomponent pollutants, for example crude oil. In the work [130], two co-immobilized Rhodococcus strains with different substrate specificities were used for degradation of a model petroleum mixture. It was found that $R$. ruber IEGM 615 more efficiently oxidized $n$-alkanes C10-C16, while $R$. opacus IEGM 249 was able to degrade naphthalene. A nitrile-degrading strain R. rhodochrous BX2 was adsorbed together with a biofilm-forming, not degrading bacterium Bacillus mojavensis M1 [100]. The M1 strain was used as a biofilm producer and BX2 was incorporated into the M1 biofilm. This technical solution was successful because the association $\mathrm{BX} 2+\mathrm{M} 1$ provided complete detoxification of a target compound (cyanide), while single $R$. rhodochrous BX2 culture oxidized no more than $80 \%$ of this toxicant at the same concentration.

However, in many cases, interactions between microorganisms in consortia/associations are not so obvious. For example, Rhodococcus sp. SLG- 6 was unable to mineralize di- $n$-octyl phthalate and biodegradation stopped after hydrolysis of ester bonds and production of phthalic acid. Although Arthrobacter sp. SLG-4 completely mineralized this compound, and the combination of these two strains resulted in a two-fold increase of biodegradation rates in comparison with Arthrobacter sp. SLG-4 alone [12]. A mixed biofilm formed by R. erythropolis PWD1 and Pseudomonas putida F1 strains was used to remove organic pollutants (in particular toluene) from waste gases [131,132]. The authors assumed that a mixed culture exhibited more robustness than pure cultures towards high pollutant concentrations. Inoculation of industrial wastewater with an algal-bacterial co-culture containing Rhodococcus sp. strain Ac-1267 and immobilization on capron fibers resulted in the formation of a stable microbial consortium and efficient removal of petroleum hydrocarbons, phenols, anionic surfactants, and heavy metals [104].

\section{Environmental Applications of Rhodococcus Biocatalysts}

Selected examples of Rhodococcus-based biocatalysts developed for environmental applications and shown in Table 1 suggest that most biocatalysts are based on whole cells, SC or IC. This can be related to biochemical complexity of the processes catalyzed, including multistep biodegradation/mineralization or biosynthesis. The only example of enzymatic Rhodococcus biocatalyst being a covalently immobilized azoreductase AzoRo from R. opacus 1CP is shown. The biocatalyst had high azo dye-degrading activity $(38 \mathrm{U} / \mathrm{mg}$ ) and stability (60 h operation) under unfavorable $(\mathrm{pH} 4)$ conditions but required supplementation with NADH, FMN, and formate dehydrogenase [103]. 
Table 1. Selected examples of Rhodococcus biocatalysts developed for environmental applications.

\begin{tabular}{|c|c|c|c|c|}
\hline Application & Short description of a Biocatalyst & Operating Conditions & Efficacy & Ref. \\
\hline \multirow[t]{2}{*}{ Treatment of wastewater containing phenol } & \multirow[t]{2}{*}{$\begin{array}{l}\text { A biocer: whole cells of } R \text {. ruber DSM } 7512 \text { embedded into } \\
\text { ceramics (alumosilicate }+\mathrm{SiO}_{2} \text { ) }\end{array}$} & Batch & $\begin{array}{l}\text { Complete degradation of phenol }(0.5 \mathrm{~g} / \mathrm{L}) \text { in } 5 \text { days; } \geq 5 \text { cycles of } \\
\text { re-using; stable for } 12 \text { months; stored at }+4{ }^{\circ} \mathrm{C} \text { for } 6 \text { months. }\end{array}$ & \multirow[t]{2}{*}[70]{} \\
\hline & & A bench-scale flow dynamic system & Degradation of $80-100 \%$ phenol $(0.5 \mathrm{~g} / \mathrm{L})$ in $6-8$ days. & \\
\hline $\begin{array}{l}\text { Treatment of wastewater containing } \\
\text { chlorophenols }\end{array}$ & $\begin{array}{l}\text { Whole cells of } R \text {. rhodochrous } \mathrm{DSM} 6263 \text { entrapped into } \\
\mathrm{k} \text {-carrageenan mixed with } \mathrm{Fe}_{3} \mathrm{O}_{4} \text { nanoparticles }\end{array}$ & Batch & $\begin{array}{l}\text { Complete degradation of chlorophenols }(0.25 \mathrm{mM}) \text { in } 5 \mathrm{~h} ; 6 \text { cycles of } \\
\text { re-using. }\end{array}$ & [96] \\
\hline \multirow{2}{*}{$\begin{array}{l}\text { Treatment of wastewater and groundwater } \\
\text { containing nitrophenols }\end{array}$} & Whole cells of R. erythropolis HL PM-1, $\mathrm{SC}^{1}$ & Batch & Complete degradation of 2,4-dinitrophenol $(0.06 \mathrm{~g} / \mathrm{L})$ in $6 \mathrm{~h}$. & \multirow{2}{*}{ [85] } \\
\hline & $\begin{array}{l}\text { Whole cells of R. erythropolis HL PM-1 embedded into agar } \\
\text { beads }\end{array}$ & A plug-flow bioreactor & $\begin{array}{l}\text { Complete degradation of } 2,4-\text { dinitrophenol }(0.005 \mathrm{~g} / \mathrm{L}) \text { without loss of } \\
\text { activity for } 14 \text { days. }\end{array}$ & \\
\hline $\begin{array}{l}\text { Treatment of wastewater containing phenol } \\
\text { and hydrocarbons }\end{array}$ & $\begin{array}{l}\text { Whole cells of R. wratislaviensis BN38 entrapped in } \\
\text { hydroxypropylcellulose/ poly(N-isopropylacrylamide) } \\
\text { cryogel, acclimated }\end{array}$ & $\begin{array}{l}\text { Semicontinuous with a gradual increase } \\
\text { of a contaminant concentration }\end{array}$ & $\begin{array}{l}\text { Complete degradation of phenol }(20 \mathrm{~g} / \mathrm{L} \text { in total) and } n \text {-hexadecane }(20 \\
\mathrm{g} / \mathrm{L} \text { in total) in } 5 \text { days; more active than SC in } 2.5 \text { times. }\end{array}$ & [91] \\
\hline $\begin{array}{l}\text { Treatment of wastewater from phenolic resin } \\
\text { manufacturing companies }\end{array}$ & $\begin{array}{l}\text { Whole cells of R. erythropolis UPV-1 adsorbed on ceramic } \\
\text { Biolite }{ }^{\circledR} \text { beads, acclimated }\end{array}$ & $\begin{array}{l}\text { A packed-bed two column bioreactor } \\
\text { with aeration }\end{array}$ & $\begin{array}{l}\text { The rate of phenol }(0.1-0.8 \mathrm{~g} / \mathrm{L}) \text { degradation } 0.4-18.0 \mathrm{~g} /(\mathrm{l} \cdot \text { day }) ; \\
\text { degradation of } 100 \% \text { formaldehyde }(0.2 \mathrm{~g} / \mathrm{L}) \text {; stable for } 50 \text { days. }\end{array}$ & [13] \\
\hline $\begin{array}{l}\text { Treatment of wastewater from phenolic resin } \\
\text { manufacturing companies }\end{array}$ & $\begin{array}{l}\text { Whole cells of R. erythropolis UPV-1 adsorbed on } \\
\text { diatomaceous earth, acclimated }\end{array}$ & An air-stirred bioreactor with clarifier & $\begin{array}{l}\text { The rate of phenol }(0.1-1.2 \mathrm{~g} / \mathrm{L}) \text { degradation } 0.1-11.5 \mathrm{~g} /(\mathrm{l} \cdot \text { day }) \text {; } \\
\text { degradation of } 100 \% \text { formaldehyde }(0.3-2.4 \mathrm{~g} / \mathrm{L}) \text {. }\end{array}$ & [67] \\
\hline $\begin{array}{l}\text { Treatment of wastewater from paper and pulp } \\
\text { industry }\end{array}$ & Whole cells of $R$. rhodochrous IEGM 107, SC & Batch & Complete degradation of dehydroabietic acid $(0.5 \mathrm{~g} / \mathrm{L})$ in 9 days. & [38] \\
\hline $\begin{array}{l}\text { Treatment of wastewater containing pharma } \\
\text { pollutants }\end{array}$ & $\begin{array}{l}\text { Whole cells of } R \text {. rhodochrous IEGM } 608 \text { adsorbed on } \\
\text { modified sawdust, acclimated }\end{array}$ & Batch & Complete degradation of drotaverine hydrochloride $(0.2 \mathrm{~g} / \mathrm{L})$ in 25 days. & [40] \\
\hline $\begin{array}{l}\text { Treatment of wastewater containing toxic } \\
\text { amides }\end{array}$ & $\begin{array}{l}\text { Whole cells of } R \text {. rhodochrous NHB-2 entrapped in agar gel } \\
\text { beads }\end{array}$ & A five-stage plug bioreactor & $\begin{array}{l}\text { Degradation of } 90-100 \% \text { acrylamide, acetamide, or propionamide (100 } \\
\mathrm{mM} \text { ) at } 45^{\circ} \mathrm{C} \text { and } \mathrm{pH} 8.5 \mathrm{in} 8 \mathrm{~h} \text {. }\end{array}$ & [83] \\
\hline Treatment of wastewater containing azo-dyes & $\begin{array}{l}\text { Azoreductase AzoRo from R. opacus } 1 \mathrm{CP} \text { covalently bound } \\
\text { to meso-cellular foams }\end{array}$ & Batch & $\begin{array}{l}38 \mathrm{U} / \mathrm{mg} \text { towards Methyl } \\
\operatorname{Red}(25 \mu \mathrm{M}) \text { at } \mathrm{pH} 4 \text {; stable for } 60 \mathrm{~h} \text {. }\end{array}$ & [103] \\
\hline $\begin{array}{l}\text { Treatment of groundwater contaminated with } \\
\text { cyanides }\end{array}$ & $\begin{array}{l}\text { Whole cells of } R \text {. rhodochrous BX2 }+ \text { B. mojavensis M1 } \\
\text { adsorbed on granular activated carbon, acclimated }\end{array}$ & A fluidized bed bioreactor & $\begin{array}{l}\text { Complete degradation of } \mathrm{CN}^{-}\left(0.05 \times 10^{-3}-7.48 \times 10^{-3} \mathrm{~g} / \mathrm{L}\right) \\
\text { continuously over a } 110 \text {-day steady-state operation period. }\end{array}$ & [100] \\
\hline $\begin{array}{l}\text { Treatment of groundwater contaminated with } \\
\text { N-nitroso- dimethylamine }\end{array}$ & Whole cells of R. ruber ENV425, self-immobilized & A propane-fed membrane bioreactor & $\begin{array}{l}\text { Degradation of }>99.95 \% \text { N-nitroso- dimethylamine }\left(7.4 \times 10^{-6}-77.0 \times\right. \\
10^{-6} \mathrm{~g} / \mathrm{L} \text { ) continuously over a } 135 \text {-day steady-state operation period. }\end{array}$ & [102] \\
\hline Treatment of wastewater containing crude oil & $\begin{array}{l}\text { Whole cells of R. opacus IEGM } 249 \text { and R. ruber IEGM } 615 \\
\text { co-immobilized on modified sawdust, acclimated }\end{array}$ & A column fluidized-bed bioreactor & $\begin{array}{l}\text { Degradation of } 70-90 \% \text { alkanes and PAHs of crude oil (2-3\%) in } 21 \text { days; } \\
4-6 \text { cycles of re-using. }\end{array}$ & {$[76,88,130$} \\
\hline Treatment of oilfield wastewater & $\begin{array}{l}\text { Whole cells of R. opacus IEGM } 249 \text { and R. ruber IEGM } 615 \\
\text { entrapped into cryo-PVA }\end{array}$ & A column bioreactor & $\begin{array}{l}\text { Degradation of } 80 \% \text { crude oil }(0.45 \mathrm{~g} / \mathrm{L}) \text { at strong }(194 \mathrm{~g} / \mathrm{L}) \\
\text { mineralization in } 21 \text { days. }\end{array}$ & {$[88,133]$} \\
\hline Bioremediation of crude oil-contaminated soil & $\begin{array}{l}\text { Whole cells of R. erythropolis IEGM } 275 \text { and R. ruber IEGM } \\
231 \text { entrapped into cryo-PVA }\end{array}$ & Model soil & Degradation of $45 \%$ crude oil (5\%) in 14 months under dry conditions. & [93] \\
\hline Bioremediation of crude oil-contaminated soil & $\begin{array}{l}\text { Pure identified strains from the IEGM Collection, SC or } \\
\text { adsorbed on hydrophobized sawdust }\end{array}$ & In situ; ex situ in a slurry bioreactor & $\begin{array}{l}\text { Degradation of } 80-90 \% \text { crude oil }(5-30 \%) \text { in cold and temperate climate } \\
\text { regions in a summer season. }\end{array}$ & [134-137] \\
\hline Waste gas treatment & $\begin{array}{l}\text { Whole cells of P. putida F1 and R. erythropolis PWD1 } \\
\text { adsorbed on polypropylene disks }\end{array}$ & A rotating biological contactor & $\begin{array}{l}\text { Degradation of } 30-90 \% \text { toluene vapors }\left(3-5 \mathrm{~g} / \mathrm{m}^{3}\right) \text { under steady-state } \\
\text { operation conditions for } 400 \text { days. }\end{array}$ & {$[131,132]$} \\
\hline Biofuel production & $\begin{array}{l}\text { Whole cells of R. jostii RHA1 pJAM2/RO00075 or } \\
\text { pTip-QC2/RO00075, SC; R. opacus PD630 pJAM2/RO00075 } \\
\text { or pTip-QC2/RO00075, SC }\end{array}$ & Batch & Lipid production $35-50 \% \mathrm{CDW}^{2}$ & [127] \\
\hline Biofuel production & Whole cells of $R$. jostii XYLAB or $R$. opacus XYLAB, SC & Batch & Lipid production $53-68 \% \mathrm{CDW}$ & [126] \\
\hline
\end{tabular}


As seen from Table 1, environmental applications of the developed Rhodococcus biocatalysts include (1) wastewater treatment to remove phenol and its chloro- and nitroderivatives, individual hydrocarbons, crude oil, formaldehyde, amides, amines, azo-dyes, cyanides, pharma pollutants (drotaverine hydrochloride), and components of pulp and paper wastes (dehydroabietic acid); (2) bioremediation of open ecosystems (groundwater, soil, and marine environments); (3) biofuel production; and (4) clean-up of polluted air. Most of the biocatalysts discussed here are laboratory prototypes awaiting future implementations in environmental biotechnologies. However, there is an oleophilic biopreparation consisting of suspended or adsorbed Rhodococcus cells in the complex with Rhodococcus biosurfactants, which was developed for bioremediation of crude oil-contaminated soils and field-tested under temperate and cold climate conditions in the Russian Federation (Urals, Western Siberia, etc) $[134,135]$. The Rhodococcus cultures used in this biopreparation were nonpathogenic and thoroughly studied strains from the Regional Specialized Collection of Alkanotrophic Microorganisms (acronym IEGM, WDCM \# 768, www.iegmcol.ru). The vast majority of the Collection strains were isolated from the local environments over the territories remediated.

Importantly, Rhodococcus biocatalysts are suitable for various bioremediation conditions, such as single introduction (bioaugmentation or batch processes) $[38,70,85,93,96,103,136]$, semicontinuous pollutant supplementation (with repeated and gradual adding of a substrate, up to 40 times in total) [91], and continuous bioreactors $[13,67,70,83,85,100,102,130,136]$. Different-type bioreactors are used that are equipped with diverse constructions, from slurry and single-column fluidized bed bioreactors to three-phase airlift and 2-5-column ones. Catalytic activities of Rhodococcus bacteria in bioreactors can differ from those in batch systems $[70,85]$, while a biocatalyst behavior in laboratory and pilot bioreactors is generally similar to the industrial scale reactor conditions.

Functional activities of Rhodococcus biocatalysts varied between $30 \%$ and $100 \%$ of the target compound removal during biodegradation processes, and between $35 \%$ and $68 \%$ of cell dried weight for the target compound synthesized. However, it is hard to compare the activities of biocatalytic systems since they depend on many factors, such as substrate (its bioavailability and toxicity), strain(s), operating regimes, and environmental conditions $(\mathrm{pH}$, temperature, humidity, salt concentration, chemical composition, and presence of other microorganisms). For example, the degrading activity of R. ruber cells immobilized into biocer [70] against phenol was 4 times lower than that of $R$. wratislavensis cells entrapped into the cryogel [91]. This could be related to differences in intrinsic phenol-degrading abilities of the strains used, operating conditions (batch and flow dynamic vs. semicontinious), or to positive effects of the cell acclimation and a gradual increase of phenol concentration [91]. In laboratory experiments, Rhodococcus strains immobilized into cryo-PVA degraded only $45 \%$ of crude oil in model soil at the initial contamination level of $5 \%(\mathrm{w} / \mathrm{w})$ within 14 months [93], whereas in open soil ecosystems, rhodococci as a component of an oleophilic biopreparation provided a removal of $80 \%-90 \%$ of crude oil at the initial contamination level of $30 \%(\mathrm{w} / \mathrm{w})$ within 3 months (summer season) [134-136]. This example reflects common differences in laboratory and field bioremediation results, indicating that higher biodegradation rates under natural conditions are probably due to enhanced self-restoring abilities of natural soil ecosystems.

The literature and our experimental data show that Rhodococcus biocatalysts compete successfully with the biocatalysts based on other microorganisms, particularly in terms of biodegradation of phenol and petroleum hydrocarbons. For example, rhodococci completely degraded phenol at concentrations of $0.1-20.0 \mathrm{~g} / \mathrm{L}$ within a duration range from $8 \mathrm{~min}$ to 8 days and removed $45 \%-100 \%$ of petroleum hydrocarbons at concentrations of $2 \%-30 \%(\mathrm{w} / \mathrm{w})$ within 5 days to 14 months (see Table 1$)$. Other referenced biocatalytic systems (based on Alcaligenes faecalis, Alcanivorax borkumensis, Bacillus cereus, Bacillus firmus, Halomonas hamiltonii, P. putida, Shewanalla chilikensis, and microbial fuel cells) provided complete phenol degradation at concentrations of $0.1-6.0 \mathrm{~g} / \mathrm{L}$ within the time periods from $12 \mathrm{~h}$ to 8 days [138-140] and a $24 \%-90 \%$ removal of petroleum hydrocarbons at their concentrations of $1 \%-16 \%$ $(\mathrm{w} / \mathrm{w})$ in 3-66 days [141-143]. 
Concerning other technological characteristics, Rhodococcus biocatalysts can be re-used from four times up to 35 cycles, and can operate continuously up to 400 days and stored for 12 months without the catalytic activity lost. Sustainability of immobilized Rhodococcus biocatalysts in long-term bioremediation processes was clearly demonstrated in soil microcosms [93]. In this study, a high number of viable $R$. erythropolis IEGM 275 and $R$. ruber IEGM 231 cells entrapped into cryo-PVA beads was maintained over 14 months in crude oil-contaminated dry (10-20\% relative humidity) soil, thus impacting the efficient oil biodegradation.

\section{Conclusions}

Rhodococcus-based biocatalysts meet modern biotechnology requirements, such as broad substrate range, high enzymatic activity, robustness, economic feasibility and environmental safety. Immobilized Rhodococcus cells can be easily recovered from the fermentation broth, regenerated and repeatedly used without significant cell losses. However, Rhodococcus biocatalysts do not pretend to be a "catalytic panacea" since each catalytic system is unique and fits particular bioprocess conditions. A present review is aimed at revealing the possible abilities of immobilized Rhodococcus cells to degrade the priority organic pollutants, mostly hydrocarbon-derived ones, thus suggesting their potential for advanced ecobiotechnological solutions. Considering the main challenges of Rhodococcus applications, such as complex growth cycle and cell pleomorphism, relatively slow growth and ecological k-strategy (persistence under non-optimal environmental conditions with low metabolic activity), there is a need for the development of knowledge-based approaches to mitigate these problems. Therefore, future developments could focus on strain improvements using genetic modifications, namely over-expression of important catabolic genes, and search for molecular inducers of target degradation pathways. Other promising approaches include acclimation of Rhodococcus to high pollutant concentrations and development of co-immobilized bacterial consortia containing rhodococci and based on synergetic metabolic interactions revealed with ecological modeling tools.

Funding: This research was funded by the Ministry of Education and Science of the Russian Federation (the State Tasks 01201353246, 01201353247, and 6.3330.2017/4.6) and the Russian Science Foundation (grant number 18-14-00140).

Conflicts of Interest: The authors declare no conflict of interest.

\section{References}

1. Chen, M.; Xu, P.; Zeng, G.; Yang, C.; Huang, D.; Zhang, J. Bioremediation of soils contaminated with polycyclic aromatic hydrocarbons, petroleum, pesticides, chlorophenols and heavy metals by composting: Applications, microbes and future research needs. Biotechnol. Adv. 2015, 33, 745-755. [CrossRef] [PubMed]

2. Ivshina, I.B.; Kuyukina, M.S.; Krivoruchko, A.V.; Elkin, A.A.; Makarov, S.O.; Cunningham, C.J.; Peshkur, T.A.; Atlas, R.M.; Philp, J.C. Oil spill problems and sustainable response strategies through new technologies. Environ. Sci. Process. Impacts 2015, 17, 1201-1219. [CrossRef] [PubMed]

3. Khatri, A.; Peerzada, M.H.; Mohsin, M.; White, M. A review on developments in dyeing cotton fabrics with reactive dyes for reducing effluent pollution. J. Clean. Prod. 2015, 87, 50-57. [CrossRef]

4. Horton, A.A.; Walton, A.; Spurgeon, D.J.; Lahive, E.; Svendsen, C. Microplastics in freshwater and terrestrial environments: Evaluating the current understanding to identify the knowledge gaps and future research priorities. Sci. Total Environ. 2017, 586, 127-141. [CrossRef] [PubMed]

5. Awasthi, K.A.; Wang, M.; Awasti, K.M.; Wang, Z.; Li, J. Environmental pollution and human body burden from improper recycling of e-waste in China: A short-review. Environ. Pollut. 2018, 243, 1310-1316. [CrossRef] [PubMed]

6. He, D.; Luo, Y.; Lu, S.; Liu, M.; Song, Y.; Lei, L. Microplastics in soils: Analytical methods, pollution characteristics and ecological risks. Trends Anal. Chem. 2018, 109, 163-172. [CrossRef]

7. Kanter, D.R.; Searchinger, T.D. A technology-forcing approach to reduce nitrogen pollution. Nat. Sustain. 2018, 1, 544-552. [CrossRef] 
8. Xu, X.; Nie, S.; Ding, H.; Hou, F.F. Environmental pollution and kidney diseases. Nat. Rev. Nephrol. 2018, 14, 313-324. [CrossRef] [PubMed]

9. Chowdhary, P.; Raj, A.; Bharagava, R.N. Environmental pollution and health hazards from distillery wastewater and treatment approaches to combat the environmental threats: A review. Chemosphere 2018, 194, 229-246. [CrossRef] [PubMed]

10. Ivshina, I.; Tyumina, E.; Vikhareva, E. Biodegradation of emerging pollutants: Focus on pharmaceuticals. Microbiol. Aust. 2018, 39, 117-122. [CrossRef]

11. Vilela, C.L.S.; Bassin, J.P.; Peixoto, R.S. Water contamination by endocrine disruptors: Impacts, microbiological aspects and trends for environmental protection. Environ. Pollut. 2018, 235, 546-559. [CrossRef] [PubMed]

12. Zhang, K.; Liu, Y.; Chen, Q.; Luo, H.; Zhu, Z.; Chen, W.; Chen, J.; Mo, Y. Biochemical pathways and enhanced degradation of di- $n$-octyl phthalate (DOP) in sequencing batch reactor (SBR) by Arthrobacter sp. SLG-4 and Rhodococcus sp. SLG-6 isolated from activated sludge. Biodegradation 2018, 29, 171-185. [CrossRef] [PubMed]

13. Prieto, M.B.; Hidalgo, A.; Serra, J.L.; Llama, M.J. Degradation of phenol by Rhodococcus erythropolis UPV-1 immobilized on Biolite ${ }^{\circledR}$ in a packed-bed reactor. J. Biotechnol. 2002, 97, 1-11. [CrossRef]

14. Megharaj, M.; Ramakrishnan, B.; Venkateswarlu, K.; Sethunathan, N.; Naidu, R. Bioremediation approaches for organic pollutants: A critical perspective. Environ. Int. 2011, 37, 1362-1375. [CrossRef] [PubMed]

15. Bajaj, S.; Singh, D.K. Biodegradation of persistent organic pollutants in soil, water and pristine sites by cold-adapted microorganisms: Mini review. Int. Biodeterior. Biodegrad. 2015, 100, 98-105. [CrossRef]

16. de Carvalho, C.C.C.R.; da Fonseca, M.M.R. The remarkable Rhodococcus erythropolis. Appl. Microbiol. Biotechnol. 2005, 67, 715-726. [CrossRef] [PubMed]

17. Larkin, M.J.; Kulakov, L.A.; Allen, C.C.R. Biodegradation and Rhodococcus-Masters of catabolic versatility. Curr. Opin. Biotechnol. 2005, 16, 282-290. [CrossRef] [PubMed]

18. Martínková, L.; Uhnáková, B.; Pátek, M.; Nešvera, J.; Křen, V. Biodegradation potential of the genus Rhodococcus. Environ. Int. 2009, 35, 162-177. [CrossRef] [PubMed]

19. Kuyukina, M.S.; Ivshina, I.B. Application of Rhodococcus in bioremediation of contaminated environments. In Biology of Rhodococcus; Alvarez, H.M., Ed.; Springer: Berlin/Heidelberg, Germany, 2010; pp. 231-262. ISBN 978-3-642-12936-0.

20. Larkin, M.J.; Kulakov, L.A.; Allen, C.C.R. Rhodococcus. In Handbook of Hydrocarbon and Lipid Microbiology; Timmis, K.N., Ed.; Springer: Berlin/Heidelberg, Germany, 2010; pp. 1839-1852. ISBN 9783540775874.

21. Yam, K.C.; van der Geize, R.; Eltis, L.D. Catabolism of aromatic compounds and steroids by Rhodococcus. In Biology of Rhodococcus; Alvarez, H.M., Ed.; Springer: Berlin/Heidelberg, Germany, 2010; pp. 133-169. ISBN 978-3-642-12936-0.

22. de Carvalho, C.C.C.R.; Costa, S.S.; Fernandes, P.; Couto, I.; Viveiros, M. Membrane transport systems and the biodegradation potential and pathogenicity of genus Rhodococcus. Front. Physiol. 2014, 5, 133. [CrossRef] [PubMed]

23. Pogorevc, M.; Faber, K. Purification and characterization of an inverting stereo- and enantioselective sec-alkylsulfatase from the gram-positive bacterium Rhodococcus ruber DSM 44541. Appl. Environ. Microbiol. 2003, 69, 2810-2815. [CrossRef] [PubMed]

24. Koch, D.J.; Chen, M.M.; Van Beilen, J.B.; Arnold, F.H. In vivo evolution of butane oxidation by terminal alkane hydroxylases AlkB and CYP153A6. Appl. Environ. Microbiol. 2009, 75, 337-344. [CrossRef] [PubMed]

25. Kim, D.; Choi, K.Y.; Yoo, M.; Choi, J.N.; Lee, C.H.; Zylstra, G.J.; Kang, B.S.; Kim, E. Benzylic and aryl hydroxylations of $m$-xylene by $o$-xylene dioxygenase from Rhodococcus sp. strain DK17. Appl. Microbiol. Biotechnol. 2010, 86, 1841-1847. [CrossRef] [PubMed]

26. Okamoto, S.; Van Petegem, F.; Patrauchan, M.A.; Eltis, L.D. AnhE, a metallochaperone involved in the maturation of a cobalt-dependent nitrile hydratase. J. Biol. Chem. 2010, 285, 25126-25133. [CrossRef] [PubMed]

27. Saa, L.; Jaureguibeitia, A.; Largo, E.; Llama, M.J.; Serra, J.L. Cloning, purification and characterization of two components of phenol hydroxylase from Rhodococcus erythropolis UPV-1. Appl. Microbiol. Biotechnol. 2010, 86, 201-211. [CrossRef] [PubMed]

28. Fernández de las Heras, L.; van der Geize, R.; Drzyzga, O.; Perera, J.; María Navarro Llorens, J. Molecular characterization of three 3-ketosteroid- $\Delta 1$-dehydrogenase isoenzymes of Rhodococcus ruber strain Chol-4. J. Steroid Biochem. Mol. Biol. 2012, 132, 271-281. [CrossRef] [PubMed] 
29. Singh, R.; Grigg, J.C.; Armstrong, Z.; Murphy, M.E.P.; Eltis, L.D. Distal heme pocket residues of B-type dye-decolorizing peroxidase: Arginine but not aspartate is essential for peroxidase activity. J. Biol. Chem. 2012, 287, 10623-10630. [CrossRef] [PubMed]

30. Martinez-Rojas, E.; Kurt, T.; Schmidt, U.; Meyer, V.; Garbe, L.A. A bifunctional enzyme from Rhodococcus erythropolis exhibiting secondary alcohol dehydrogenase-catalase activities. Appl. Microbiol. Biotechnol. 2014, 98, 9249-9258. [CrossRef] [PubMed]

31. Ivshina, I.B.; Kuyukina, M.S.; Krivoruchko, A.V.; Barbe, V.; Fischer, C. Draft genome sequence of propaneand butane-oxidizing actinobacterium Rhodococcus ruber IEGM 231. Genome Announc. 2014, 2, e1297-14. [CrossRef] [PubMed]

32. McLeod, M.P.; Warren, R.L.; Hsiao, W.W.L.; Araki, N.; Myhre, M.; Fernandes, C.; Miyazawa, D.; Wong, W.; Lillquist, A.L.; Wang, D.; et al. The complete genome of Rhodococcus sp. RHA1 provides insights into a catabolic powerhouse. Proc. Natl. Acad. Sci. USA 2006, 103, 15582-15587. [CrossRef] [PubMed]

33. Takeda, H.; Shimodaira, J.; Yukawa, K.; Hara, N.; Kasai, D.; Miyauchi, K.; Masai, E.; Fukuda, M. Dual two-component regulatory systems are involved in aromatic compound degradation in a polychlorinated-biphenyl degrader, Rhodococcus jostii RHA1. J. Bacteriol. 2010, 192, 4741-4751. [CrossRef] [PubMed]

34. Li, J.; Chen, J.A.; Zhao, Q.; Li, X.; Shu, W. Bioremediation of environmental endocrine disruptor di- $n$-butyl phthalate ester by Rhodococcus ruber. Chemosphere 2006, 65, 1627-1633. [CrossRef] [PubMed]

35. Elkin, A.A.; Kylosova, T.I.; Grishko, V.V.; Ivshina, I.B. Enantioselective oxidation of sulfides to sulfoxides by Gordonia terrae IEGM 136 and Rhodococcus rhodochrous IEGM 66. J. Mol. Catal. B Enzym. 2013, 89, 82-85. [CrossRef]

36. Gilan, I.; Sivan, A. Effect of proteases on biofilm formation of the plastic-degrading actinomycete Rhodococcus ruber C208. FEMS Microbiol. Lett. 2013, 342, 18-23. [CrossRef] [PubMed]

37. He, Z.; Niu, C.; Lu, Z. Individual or synchronous biodegradation of di-n-butyl phthalate and phenol by Rhodococcus ruber strain DP-2. J. Hazard. Mater. 2014, 273, 104-109. [CrossRef] [PubMed]

38. Cheremnykh, K.M.; Luchnikova, N.A.; Grishko, V.V.; Ivshina, I.B. Bioconversion of ecotoxic dehydroabietic acid using Rhodococcus actinobacteria. J. Hazard. Mater. 2018, 346, 103-112. [CrossRef] [PubMed]

39. O'Grady, D.; Evangelista, S.; Yargeau, V. Removal of aqueous $17 \alpha$-ethinylestradiol by Rhodococcus species. Environ. Eng. Sci. 2009, 26, 1393-1400. [CrossRef]

40. Ivshina, I.B.; Vikhareva, E.V.; Richkova, M.I.; Mukhutdinova, A.N.; Karpenko, J.N. Biodegradation of drotaverine hydrochloride by free and immobilized cells of Rhodococcus rhodochrous IEGM 608. World J. Microbiol. Biotechnol. 2012, 28, 2997-3006. [CrossRef] [PubMed]

41. Alvarez, H.M.; Silva, R.A. Metabolic diversity and flexibility for hydrocarbon biodegradation by Rhodococcus. In Actinobacteria: Application in Bioremediation and Production of Industrial Enzymes; Amoroso, M.J., Benimeli, C.S., Cuozzo, S.A., Eds.; CRC Press: Boca Raton, FL, USA; London, UK; New York, NY, USA, 2013; pp. 241-273.

42. Gilan (Orr), I.; Hadar, Y.; Sivan, A. Colonization, biofilm formation and biodegradation of polyethylene by a strain of Rhodococcus ruber. Appl. Microbiol. Biotechnol. 2004, 65, 97-104. [CrossRef]

43. Sivan, A.; Szanto, M.; Pavlov, V. Biofilm development of the polyethylene-degrading bacterium Rhodococcus ruber. Appl. Microbiol. Biotechnol. 2006, 72, 346-352. [CrossRef] [PubMed]

44. Krueger, M.C.; Harms, H.; Schlosser, D. Prospects for microbiological solutions to environmental pollution with plastics. Appl. Microbiol. Biotechnol. 2015, 99, 8857-8874. [CrossRef] [PubMed]

45. Lang, S.; Philp, J.C. Surface-active lipids in rhodococci. Antonie Van Leeuwenhoek 1998, 74, 59-70. [CrossRef] [PubMed]

46. Kuyukina, M.S.; Ivshina, I.B. Rhodococcus biosurfactants: Biosynthesis, properties, and potential applications. In Biology of Rhodococcus; Alvarez, H.M., Ed.; Springer: Berlin/Heidelberg, Germany, 2010; pp. 291-313. ISBN 978-3-642-12936-0.

47. Cortes, M.A.L.R.M.; de Carvalho, C.C.C.R. Effect of carbon sources on lipid accumulation in Rhodococcus cells. Biochem. Eng. J. 2015, 94, 100-105. [CrossRef]

48. Pieper-Furst, U.; Madkour, M.H.; Mayer, F.; Steinbuchel, A. Identification of the region of a 14-kilodalton protein of Rhodococcus ruber that is responsible for the binding of this phasin to polyhydroxyalkanoic acid granules. J. Bacteriol. 1995, 177, 2513-2523. [CrossRef] [PubMed] 
49. Hori, K.; Kobayashi, A.; Ikeda, H.; Unno, H. Rhodococcus aetherivorans IAR1, a new bacterial strain synthesizing poly(3-hydroxybutyrate-co-3-hydroxyvalerate) from toluene. J. Biosci. Bioeng. 2009, 107, 145-150. [CrossRef]

50. Kuyukina, M.S.; Ivshina, I.B.; Baeva, T.A.; Kochina, O.A.; Gein, S.V.; Chereshnev, V.A. Trehalolipid biosurfactants from nonpathogenic Rhodococcus actinobacteria with diverse immunomodulatory activities. New Biotechnol. 2015, 32, 559-568. [CrossRef] [PubMed]

51. Koller, M.; Gasser, I.; Schmid, F.; Berg, G. Linking ecology with economy: Insights into polyhydroxyalkanoate-producing microorganisms. Eng. Life Sci. 2011, 11, 222-237. [CrossRef]

52. Vandeputte, O.; Öden, S.; Mol, A.; Vereecke, D.; Goethals, K.; El Jaziri, M.; Prinsen, E. Biosynthesis of auxin by the gram-positive phytopathogen Rhodococcus fascians is controlled by compounds specific to infected plant tissues. Appl. Environ. Microbiol. 2005, 71, 1169-1177. [CrossRef]

53. Kämpfer, P.; Dott, W.; Martin, K.; Glaeser, S.P. Rhodococcus defluvii sp. nov., isolated from wastewater of a bioreactor and formal proposal to reclassify [Corynebacterium hoagii] and Rhodococcus equi as Rhodococcus hoagii comb. nov. Int. J. Syst. Evol. Microbiol. 2014, 64, 755-761. [CrossRef]

54. Koronelli, T.V. Principles and methods for raising the efficiency of biological degradation of hydrocarbons in the environment: Review. Appl. Biochem. Microbiol. 1996, 32, 519-525. [CrossRef]

55. Qin, S.; Xing, K.; Jiang, J.H.; Xu, L.H.; Li, W.J. Biodiversity, bioactive natural products and biotechnological potential of plant-associated endophytic actinobacteria. Appl. Microbiol. Biotechnol. 2011, 89, 457-473. [CrossRef] [PubMed]

56. Ivshina, I.B. Current situation and challenges of specialized microbial resource centres in Russia. Microbiology 2012, 81, 509-516. [CrossRef]

57. Sorkhoh, N.A.; Ghannoum, M.A.; Ibrahim, A.S.; Stretton, R.J.; Radwan, S.S. Crude oil and hydrocarbon-degrading strains of Rhodococcus rhodochrous isolated from soil and marine environments in Kuwait. Environ. Pollut. 1990, 65, 1-17. [CrossRef]

58. Paliwal, V.; Puranik, S.; Purohit, H.J. Integrated perspective for effective bioremediation. Appl. Biochem. Biotechnol. 2012, 166, 903-924. [CrossRef] [PubMed]

59. Panicker, G.; Mojib, N.; Aislabie, J.; Bej, A.K. Detection, expression and quantitation of the biodegradative genes in Antarctic microorganisms using PCR. Antonie van Leeuwenhoek 2010, 97, 275-287. [CrossRef] [PubMed]

60. Bej, A.K.; Saul, D.; Aislabie, J. Cold-tolerant alkane-degrading Rhodococcus species from Antarctica. Polar Biol. 2000, 23, 100-105. [CrossRef]

61. Whyte, L.G.; Goalen, B.; Hawari, J.; Labbe, D.; Greer, C.W.; Nahir, M. Bioremediation treatability assessment of hydrocarbon-contaminated soils from Eureka, Nunavut. Cold Reg. Sci. Technol. 2001, 32, 121-132. [CrossRef]

62. de Carvalho, C.C.C.R. Adaptation of Rhodococcus erythropolis cells for growth and bioremediation under extreme conditions. Res. Microbiol. 2012, 163, 125-136. [CrossRef] [PubMed]

63. Yamashita, S.; Satoi, M.; Iwasa, Y.; Honda, K.; Sameshima, Y.; Omasa, T.; Kato, J.; Ohtake, H. Utilization of hydrophobic bacterium Rhodococcus opacus B-4 as whole-cell catalyst in anhydrous organic solvents. Appl. Microbiol. Biotechnol. 2007, 74, 761-767. [CrossRef] [PubMed]

64. Retamal-Morales, G.; Mehnert, M.; Schwabe, R.; Tischler, D.; Schlömann, M.; Levicán, G.J. Genomic characterization of the arsenic-tolerant actinobacterium, Rhodococcus erythropolis S43. Solid State Phenom. 2017, 262, 660-663. [CrossRef]

65. Kuyukina, M.; Krivoruchko, A.; Ivshina, I. Hydrocarbon- and metal-polluted soil bioremediation: Progress and challenges. Microbiol. Aust. 2018, 39, 133-136. [CrossRef]

66. Kratzer, R.; Woodley, J.M.; Nidetzky, B. Rules for biocatalyst and reaction engineering to implement effective, NAD(P)H-dependent, whole cell bioreductions. Biotechnol. Adv. 2015, 33, 1641-1652. [CrossRef] [PubMed]

67. Prieto, M.B.; Hidalgo, A.; Rodríguez-Fernández, C.; Serra, J.L.; Llama, M.J. Biodegradation of phenol in synthetic and industrial wastewater by Rhodococcus erythropolis UPV-1 immobilized in an air-stirred reactor with clarifier. Appl. Microbiol. Biotechnol. 2002, 58, 853-859. [CrossRef] [PubMed]

68. Suttinun, O.; Müller, R.; Luepromchai, E. Cometabolic degradation of trichloroethene by Rhodococcus sp. strain L4 immobilized on plant materials rich in essential oils. Appl. Environ. Microbiol. 2010, 76, 4684-4690. [CrossRef] [PubMed] 
69. Tapingkae, W.; Parkin, K.L.; Tanasupawat, S.; Kruenate, J.; Benjakul, S.; Visessanguan, W. Whole cell immobilisation of Natrinema gari BCC 24369 for histamine degradation. Food Chem. 2010, 120, 842-849. [CrossRef]

70. Pannier, A.; Mkandawire, M.; Soltmann, U.; Pompe, W.; Böttcher, H. Biological activity and mechanical stability of sol-gel-based biofilters using the freeze-gelation technique for immobilization of Rhodococcus ruber. Appl. Microbiol. Biotechnol. 2012, 93, 1755-1767. [CrossRef] [PubMed]

71. Takei, T.; Yamasaki, M.; Yoshida, M. Cesium accumulation of Rhodococcus erythropolis CS98 strain immobilized in hydrogel matrices. J. Biosci. Bioeng. 2014, 117, 497-500. [CrossRef] [PubMed]

72. Eş, I.; Vieira, J.D.G.; Amaral, A.C. Principles, techniques, and applications of biocatalyst immobilization for industrial application. Appl. Microbiol. Biotechnol. 2015, 99, 2065-2082. [CrossRef] [PubMed]

73. Cappello, S.; Volta, A.; Santisi, S.; Morici, C.; Mancini, G.; Quatrini, P.; Genovese, M.; Yakimov, M.M.; Torregrossa, M. Oil-degrading bacteria from a membrane bioreactor (BF-MBR) system for treatment of saline oily waste: Isolation, identification and characterization of the biotechnological potential. Int. Biodeterior. Biodegrad. 2016, 110, 235-244. [CrossRef]

74. Zur, J.; Wojcieszyńska, D.; Guzik, U. Metabolic responses of bacterial cells to immobilization. Molecules 2016, 21, 958. [CrossRef] [PubMed]

75. Andryushina, V.; Balabanova, T.; Beklemishev, A.; Varfolomeev, S.; Vodyakova, M.; Demakov, V.; Ditchenko, T.; Dzhavahiya, V.; Drozdova, M.; Efremenko, E.; et al. Immobilized Cells: Biocatalysts and Processes; Publishing Center RIOR: Moscow, Russia, 2018; ISBN 978-5-369-02004-3.

76. Kuyukina, M.S.; Ivshina, I.B.; Serebrennikova, M.K.; Krivoruchko, A.V.; Korshunova, I.O.; Peshkur, T.A.; Cunningham, C.J. Oilfield wastewater biotreatment in a fluidized-bed bioreactor using co-immobilized Rhodococcus cultures. J. Environ. Chem. Eng. 2017, 5, 1252-1260. [CrossRef]

77. Wang, X.; Gong, Z.; Li, P.; Zhang, L.; Hu, X. Degradation of pyrene and benzo(a)pyrene in contaminated soil by immobilized fungi. Environ. Eng. Sci. 2008, 25, 677-684. [CrossRef]

78. Li, J.; Guo, C.; Liao, C.; Zhang, M.; Liang, X.; Lu, G.; Yang, C.; Dang, Z. A bio-hybrid material for adsorption and degradation of phenanthrene: Bacteria immobilized on sawdust coated with a silica layer. RSC Adv. 2016, 6, 107189-107199. [CrossRef]

79. Xiong, B.; Zhang, Y.; Hou, Y.; Arp, H.P.H.; Reid, B.J.; Cai, C. Enhanced biodegradation of PAHs in historically contaminated soil by M. gilvum inoculated biochar. Chemosphere 2017, 182, 316-324. [CrossRef] [PubMed]

80. Coles, C.A.; Patel, T.R.; Akinnola, A.P.; Helleur, R.J. Influence of bulking agents, fertilizers and bacteria on the removal of diesel from a Newfoundland soil. Soil Sediment Contam. 2009, 18, 383-396. [CrossRef]

81. Rivelli, V.; Franzetti, A.; Gandolfi, I.; Cordoni, S.; Bestetti, G. Persistence and degrading activity of free and immobilised allochthonous bacteria during bioremediation of hydrocarbon-contaminated soils. Biodegradation 2013, 24, 1-11. [CrossRef] [PubMed]

82. Kauppi, S.; Sinkkonen, A.; Romantschuk, M. Enhancing bioremediation of diesel-fuel-contaminated soil in a boreal climate: Comparison of biostimulation and bioaugmentation. Int. Biodeterior. Biodegrad. 2011, 65, 359-368. [CrossRef]

83. Chand, D.; Kumar, H.; Sankhian, U.D.; Kumar, D.; Vitzthum, F.; Bhalla, T.C. Treatment of simulated wastewater containing toxic amides by immobilized Rhodococcus rhodochrous NHB-2 using a highly compact 5-stage plug flow reactor. World J. Microbiol. Biotechnol. 2004, 20, 679-686. [CrossRef]

84. Junter, G.A.; Jouenne, T. Immobilized viable microbial cells: From the process to the proteome... or the cart before the horse. Biotechnol. Adv. 2004, 22, 633-658. [CrossRef] [PubMed]

85. Kitova, A.E.; Kuvichkina, T.N.; Arinbasarova, A.Y.; Reshetilov, A.N. Degradation of 2,4-dinitrophenol by free and immobilized cells of Rhodococcus erythropolis HL PM-1. Appl. Biochem. Microbiol. 2004, 40, 307-311. [CrossRef]

86. Claudino, M.J.C.; Soares, D.; Van Keulen, F.; Marques, M.P.C.; Cabral, J.M.S.; Fernandes, P. Immobilization of mycobacterial cells onto silicone-Assessing the feasibility of the immobilized biocatalyst in the production of androstenedione from sitosterol. Bioresour. Technol. 2008, 99, 2304-2311. [CrossRef] [PubMed]

87. Junter, G.A.; Coquet, L.; Vilain, S.; Jouenne, T. Immobilized-cell physiology: Current data and the potentialities of proteomics. Enzym. Microb. Technol. 2002, 31, 201-212. [CrossRef]

88. Kuyukina, M.S.; Ivshina, I.B.; Serebrennikova, M.K.; Krivorutchko, A.B.; Podorozhko, E.A.; Ivanov, R.V.; Lozinsky, V.I. Petroleum-contaminated water treatment in a fluidized-bed bioreactor with immobilized Rhodococcus cells. Int. Biodeterior. Biodegrad. 2009, 63, 427-432. [CrossRef] 
89. Shumkova, E.S.; Solyanikova, I.P.; Plotnikova, E.G.; Golovleva, L.A. Phenol degradation by Rhodococcus opacus strain 1G. Appl. Biochem. Microbiol. 2009, 45, 51-57. [CrossRef]

90. Ivshina, I.B.; Kuyukina, M.S.; Krivoruchko, A.V.; Plekhov, O.A.; Naimark, O.B.; Podorozhko, E.A.; Lozinsky, V.I. Biosurfactant-enhanced immobilization of hydrocarbon-oxidizing Rhodococcus ruber on sawdust. Appl. Microbiol. Biotechnol. 2013, 97, 5315-5327. [CrossRef] [PubMed]

91. Hristov, A.E.; Christova, N.E.; Kabaivanova, L.V.; Nacheva, L.V.; Stoineva, I.B.; Petrov, P.D. Simultaneous biodegradation of phenol and $n$-hexadecane by cryogel immobilized biosurfactant producing strain Rhodococcus wratislaviensis BN38. Pol. J. Microbiol. 2016, 65, 287-293. [CrossRef] [PubMed]

92. Quek, E.; Ting, Y.P.; Tan, H.M. Rhodococcus sp. F92 immobilized on polyurethane foam shows ability to degrade various petroleum products. Bioresour. Technol. 2006, 97, 32-38. [CrossRef] [PubMed]

93. Kuyukina, M.S.; Ivshina, I.B.; Serebrennikova, M.K.; Rubtsova, E.V.; Krivoruchko, A.V. Simultaneous species-specific PCR detection and viability testing of poly(vinyl alcohol) cryogel-entrapped Rhodococcus spp. after their exposure to petroleum hydrocarbons. J. Microbiol. Methods 2013, 94, 135-140. [CrossRef] [PubMed]

94. Derikvand, P.; Etemadifar, Z.; Biria, D. Taguchi optimization of dibenzothiophene biodesulfurization by Rhodococcus erythropolis R1 immobilized cells in a biphasic system. Int. Biodeterior. Biodegrad. 2014, 86, 343-348. [CrossRef]

95. Bhasarkar, J.B.; Dikshit, P.K.; Moholkar, V.S. Ultrasound assisted biodesulfurization of liquid fuel using free and immobilized cells of Rhodococcus rhodochrous MTCC 3552: A mechanistic investigation. Bioresour. Technol. 2015, 187, 369-378. [CrossRef] [PubMed]

96. Hou, J.; Liu, F.; Wu, N.; Ju, J.; Yu, B. Efficient biodegradation of chlorophenols in aqueous phase by magnetically immobilized aniline-degrading Rhodococcus rhodochrous strain. J. Nanobiotechnology 2016, 14, 5. [CrossRef] [PubMed]

97. Omarova, E.O.; Lobakova, E.S.; Dolnikova, G.A.; Nekrasova, V.V.; Idiatulov, R.K.; Kashcheeva, P.B.; Perevertailo, N.G.; Dedov, A.G. Immobilization of bacteria on polymer matrices for degradation of crude oil and oil products. Mosc. Univ. Biol. Sci. Bull. 2012, 67, 24-30. [CrossRef]

98. Kovalenko, G.A.; Perminova, L.V.; Chuenko, T.V.; Ivshina, I.B.; Kuyukina, M.S.; Rychkova, M.I.; Philp, J.K. Carbon-containing macrostructured ceramic carriers for adsorption immobilization of enzymes and microorganisms. 5. Immobilization of yeast non-growing cells and alkanotrophic Rhodococcus growing cells. Biotechol. Russ. 2006, 1, 102-113.

99. Cubitto, M.A.; Gentili, A.R. Bioremediation of crude oil-contaminated soil by immobilized bacteria on an agroindustrial waste-Sunflower seed husks. Bioremediat. J. 2015, 19, 277-286. [CrossRef]

100. An, X.; Cheng, Y.; Huang, M.; Sun, Y.; Wang, H.; Chen, X.; Wang, J.; Li, D.; Li, C. Treating organic cyanide-containing groundwater by immobilization of a nitrile-degrading bacterium with a biofilm-forming bacterium using fluidized bed reactors. Environ. Pollut. 2018, 237, 908-916. [CrossRef] [PubMed]

101. Kuyukina, M.S.; Ivshina, I.B.; Gavrin, A.Y.; Podorozhko, E.A.; Lozinsky, V.I.; Jeffree, C.E.; Philp, J.C. Immobilization of hydrocarbon-oxidizing bacteria in poly(vinyl alcohol) cryogels hydrophobized using a biosurfactant. J. Microbiol. Methods 2006, 65, 596-603. [CrossRef] [PubMed]

102. Hatzinger, P.B.; Condee, C.; McClay, K.R.; Togna, A.P.; Fournier, D.; Hawari, J.; Halasz, A.; Streger, S.H.; McClay, K.R.; Masuda, H.; et al. Aerobic treatment of N-nitrosodimethylamine in a propane-fed membrane bioreactor. Water Res. 2011, 45, 254-262. [CrossRef] [PubMed]

103. Qi, J.; Anke, M.K.; Szymańska, K.; Tischler, D. Immobilization of Rhodococcus opacus 1CP azoreductase to obtain azo dye degrading biocatalysts operative at acidic pH. Int. Biodeterior. Biodegrad. 2017, 118, 89-94. [CrossRef]

104. Safonova, E.; Kvitko, K.V.; Iankevitch, M.I.; Surgko, L.F.; Afti, I.A.; Reisser, W. Biotreatment of industrial wastewater by selected algal-bacterial consortia. Eng. Life Sci. 2004, 4, 347-353. [CrossRef]

105. Bendinger, B.; Rijnaarts, H.H.M.; Altendorf, K.; Zehnder, A.J.B. Physicochemical cell surface and adhesive properties of coryneform bacteria related to the presence and chain length of mycolic acids. Appl. Environ. Microbiol. 1993, 59, 3973-3977. [PubMed]

106. Iwabuchi, N.; Sunairi, M.; Anzai, H.; Morisaki, H.; Nakajima, M. Relationships among colony morphotypes, cell-surface properties and bacterial adhesion to substrata in Rhodococcus. Colloids Surf. B Biointerfaces 2003, 30, 51-60. [CrossRef]

107. de Mesquita, L.M.S.; Lins, F.F.; Torem, M.L. Interaction of a hydrophobic bacterium strain in a hematite-quartz flotation system. Int. J. Miner. Process. 2003, 71, 31-44. [CrossRef] 
108. Li, H.; Zhang, M.; Li, C.; Yang, X.; Li, A.; Zhang, L. Bioadsorption behavior of Rhodococcus opacus on the surface of calcium and magnesium minerals. JOM 2015, 67, 382-390. [CrossRef]

109. Lopez, L.Y.; Merma, A.G.; Torem, M.L.; Pino, G.H. Fundamental aspects of hematite flotation using the bacterial strain Rhodococcus ruber as bioreagent. Miner. Eng. 2015, 75, 63-69. [CrossRef]

110. Pen, Y.; Zhang, Z.J.; Morales-García, A.L.; Mears, M.; Tarmey, D.S.; Edyvean, R.G.; Banwart, S.A.; Geoghegan, M. Effect of extracellular polymeric substances on the mechanical properties of Rhodococcus. Biochim. Biophys. Acta Biomembr. 2015, 1848, 518-526. [CrossRef]

111. Lehocký, M.; St'ahel, P.; Koutný, M.; Čech, J.; Institoris, J.; Mráček, A. Adhesion of Rhodococcus sp. S3E2 and Rhodococcus sp. S3E3 to plasma prepared Teflon-like and organosilicon surfaces. J. Mater. Process. Technol. 2009, 209, 2871-2875. [CrossRef]

112. Gertler, G.; Brudo, I.; Kenig, R.; Fleminger, G.A. $\mathrm{TiO}_{2}$-binding protein isolated from Rhodococcus strain GIN-1 (NCIMB 40340)—Purification, properties and potential applications. Materialwissenschaft und Werkstofftechnik 2003, 34, 1138-1144. [CrossRef]

113. Fleminger, G.; Shabtai, Y. Direct and rapid analysis of the adhesion of bacteria to solid surfaces: Interaction of fluorescently labeled Rhodococcus strain GIN-1 (NCIMB 40340) cells with titanium-rich particles. Appl. Environ. Microbiol. 1995, 61, 4357-4361. [PubMed]

114. Siegmann, A.; Komarska, A.; Betzalel, Y.; Brudo, I.; Jindou, S.; Mor, G.; Fleminger, G. The titanium binding protein of Rhodococcus ruber GIN1 (NCIMB 40340) is a cell-surface homolog of the cytosolic enzyme dihydrolipoamide dehydrogenase. J. Mol. Recognit. 2009, 22, 138-145. [CrossRef] [PubMed]

115. Møretrø, T.; Sharifzadeh, S.; Langsrud, S.; Heir, E.; Rickard, A.H. Coaggregation between Rhodococcus and Acinetobacter strains isolated from the food industry. Can. J. Microbiol. 2015, 61, 503-512. [CrossRef] [PubMed]

116. Podorozhko, E.A.; Lozinsky, V.I.; Ivshina, I.B.; Kuyukina, M.S.; Krivorutchko, A.B.; Philp, J.C.; Cunningham, C.J. Hydrophobised sawdust as a carrier for immobilisation of the hydrocarbon-oxidizing bacterium Rhodococcus ruber. Bioresour. Technol. 2008, 99, 2001-2008. [CrossRef]

117. Kuyukina, M.; Ivshina, I.; Krivoruchko, A.; Podorozhko, E.; Lozinsky, V.; Cunningham, C.; Philp, J. Novel biocatalysts based on immobilized Rhodococcus cells for oil-contaminated water purification. J. Biotechnol. 2007, 2, S99-S100. [CrossRef]

118. Nwankwoala, A.U.; Egiebor, N.O.; Nyavor, K. Enhanced biodegradation of methylhydrazine and hydrazine contaminated NASA wastewater in fixed-film bioreactor. Biodegradation 2001, 12, 1-10. [CrossRef] [PubMed]

119. Kuyukina, M.S.; Ivshina, I.B.; Rubtsova, E.V.; Ivanov, R.V.; Lozinsky, V.I. Adsorptive immobilization of rhodococcal cells in hydrophobized derivatives of wide-pore poly(acrylamide) cryogel. Appl. Biochem. Microbiol. 2011, 47, 158-164. [CrossRef]

120. Lozinsky, V.I.; Galaev, I.Y.; Plieva, F.M.; Savina, I.N.; Jungvid, H.; Mattiasson, B. Polymeric cryogels as promising materials of biotechnological interest. Trends Biotechnol. 2003, 21, 445-451. [CrossRef] [PubMed]

121. Ivshina, I.B.; Kuyukina, M.S.; Krivoruchko, A.V. Immobilization of hydrocarbon-oxidating Rhodococcus as a factor for the strength of oil remediation. In Immobilized Cells: Biocatalysts and Processes; Publishing Center RIOR: Moscow, Russia, 2018; pp. 409-428. ISBN 978-5-369-02004-3.

122. Adamczyk, Z.; Siwek, B.; Zembala, M.; Weroński, P. Kinetics of localized adsorption of colloid particles. Langmuir 1992, 8, 2605-2610. [CrossRef]

123. Kuyukina, M.S.; Ivshina, I.B.; Serebrennikova, M.K.; Osipenko, M.A.; Nyashin, Y.I. Experimental and theoretical studies of the actinobacterial immobilization process in a column fluidized-bed bioreactor. Russ. J. Biomech. 2012, 16, 74-81.

124. Kuyukina, M.S.; Ivshina, I.B.; Osipenko, M.A.; Nyashin, Y.I.; Tyulenyova, A.N.; Serebrennikova, M.K.; Krivoruchko, A.V. A kinetic model of bacterial cell immobilization process on the solid carrier. Russ. J. Biomech. 2007, 11, 76-84.

125. Krivoruchko, A.V.; Iziumova, A.Y.; Kuyukina, M.S.; Plekhov, O.A.; Naimark, O.B.; Ivshina, I.B. Adhesion of Rhodococcus ruber IEGM 342 to polystyrene studied using contact and non-contact temperature measurement techniques. Appl. Microbiol. Biotechnol. 2018, 102, 8525-8536. [CrossRef] [PubMed]

126. Xiong, X.; Wang, X.; Chen, S. Engineering of a xylose metabolic pathway in Rhodococcus strains. Appl. Environ. Microbiol. 2012, 78, 5483-5491. [CrossRef] [PubMed]

127. Hernández, M.A.; Comba, S.; Arabolaza, A.; Gramajo, H.; Alvarez, H.M. Overexpression of a phosphatidic acid phosphatase type 2 leads to an increase in triacylglycerol production in oleaginous Rhodococcus strains. Appl. Microbiol. Biotechnol. 2015, 99, 2191-2207. [CrossRef] [PubMed] 
128. García-Hidalgo, J.; Hormigo, D.; Prieto, M.A.; Arroyo, M.; de la Mata, I. Extracellular production of Streptomyces exfoliatus poly(3-hydroxybutyrate) depolymerase in Rhodococcus sp. T104: Determination of optimal biocatalyst conditions. Appl. Microbiol. Biotechnol. 2012, 93, 1975-1988. [CrossRef]

129. Iida, T.; Moteki, Y.; Nakamura, K.; Taguchi, K.; Otagiri, M.; Asanuma, M.; Dohmae, N.; Usami, R. Functional expression of three Rieske non-heme iron oxygenases derived from Actinomycetes in Rhodococcus species for investigation of their degradation capabilities of dibenzofuran and chlorinated dioxins. Biosci. Biotechnol. Biochem. 2009, 73, 822-827. [CrossRef] [PubMed]

130. Serebrennikova, M.K.; Kuyukina, M.S.; Krivoruchko, A.V.; Ivshina, I.B. Adaptation of coimmobilized Rhodococcus cells to oil hydrocarbons in a column bioreactor. Appl. Biochem. Microbiol. 2014, 50, 265-272. [CrossRef]

131. Vinage, I.; von Rohr, P.R. Biological waste gas treatment with a modified rotating biological contactor. I. Control of biofilm growth and long-term performance. Bioprocess Biosyst. Eng. 2003, 26, 69-74. [CrossRef] [PubMed]

132. Vinage, I.; von Rohr, P.R. Biological waste gas treatment with a modified rotating biological contactor. II. Effect of operating parameters on process performance and mathematical modeling. Bioprocess Biosyst. Eng. 2003, 26, 75-82. [CrossRef] [PubMed]

133. Serebrennikova, M.K.; Golovina, E.E.; Kuyukina, M.S.; Ivshina, I.B. A consortium of immobilized rhodococci for oilfield wastewater treatment in a column bioreactor. Appl. Biochem. Microbiol. 2017, 53, 435-440. [CrossRef]

134. Kuyukina, M.S.; Ivshina, I.B. An Oleophilic Preparation for Oil-Contaminated Soil Treatment. RF Patent 2180276, 10 March 2002.

135. Ivshina, I.B.; Kostarev, S.M.; Kuyukina, M.S.; Zakshevskaya, L.V. Bioremediation Method for Soils Contaminated with Oil or Oil Products. RF Patent 2193464, 27 November 2002.

136. Kuyukina, M.S.; Ivshina, I.B.; Ritchkova, M.I.; Philp, J.C.; Cunningham, C.J.; Christofi, N.; Kuyukina, M.S.; Ivshina, I.B.; Ritchkova, M.I.; Philp, J.C.; et al. Bioremediation of crude oil-contaminated soil using slurry-phase biological treatment and land farming techniques. Soil Sediment Contam. 2003, 12, 85-99. [CrossRef]

137. Ivshina, I.B.; Kuyukina, M.S.; Krivoruchko, A.V. Hydrocarbon-oxidizing bacteria and their potential in eco-biotechnology and bioremediation. In Microbial Resources; Kurtboke, I., Ed.; Elsevier Inc.: Oxford, UK, 2017; pp. 121-148. ISBN 978-0-12-804765-1.

138. Banerjee, A.; Ghoshal, A.K. Biodegradation of phenol by calcium-alginate immobilized Bacillus cereus in a packed bed reactor and determination of the mass transfer correlation. J. Environ. Chem. Eng. 2016, 4, 1523-1529. [CrossRef]

139. Wang, Y.; Chen, H.; Liu, Y.-X.; Ren, R.-P.; Lv, Y.-K. An adsorption-release-biodegradation system for simultaneous biodegradation of phenol and ammonium in phenol-rich wastewater. Bioresour. Technol. 2016, 211, 711-719. [CrossRef] [PubMed]

140. Kurzbaum, E.; Raizner, Y.; Cohen, O.; Suckeveriene, R.Y.; Kulikov, A.; Hakimi, B.; Kruh, L.I.; Armon, R.; Farber, Y.; Menashe, O. Encapsulated Pseudomonas putida for phenol biodegradation: Use of a structural membrane for construction of a well-organized confined particle. Water Res. 2017, 121, 37-45. [CrossRef] [PubMed]

141. Kadri, T.; Magdouli, S.; Rouissi, T.; Brar, S.K. Ex-situ biodegradation of petroleum hydrocarbons using Alcanivorax borkumensis enzymes. Biochem. Eng. J. 2018, 132, 279-287. [CrossRef]

142. Suganthi, S.H.; Murshid, S.; Sriram, S.; Ramani, K. Enhanced biodegradation of hydrocarbons in petroleum tank bottom oil sludge and characterization of biocatalysts and biosurfactants. J. Environ. Manag. 2018, 220, 87-95. [CrossRef]

143. Morris, J.M.; Jin, S. Enhanced biodegradation of hydrocarbon-contaminated sediments using microbial fuel cells. J. Hazard. Mater. 2012, 213-214, 474-477. [CrossRef] [PubMed]

(C) 2019 by the authors. Licensee MDPI, Basel, Switzerland. This article is an open access article distributed under the terms and conditions of the Creative Commons Attribution (CC BY) license (http:/ / creativecommons.org/licenses/by/4.0/). 